\title{
MENINGITIS AND ENCEPHALITIS IN POLAND IN 2018*
}

\section{ZAPALENIA OPON MÓZGOWO-RDZENIOWYCH I ZAPALENIA MÓZGU W POLSCE W 2018 ROKU*}

\author{
National Institute of Public Health - National Institute of Hygiene \\ Departament of Epidemiology of Infectious Diseases and Surveillance \\ Narodowy Instytut Zdrowia Publicznego - Państwowy Zakład Higieny w Warszawie \\ Zakład Epidemiologii Chorób Zakaźnych i Nadzoru
}

\begin{abstract}
INTRODUCTION. Infectious diseases of the nervous system are most often manifested in the form of meningitis. We distinguish meningitis and/or encephalitis according to their etiology, i.e. bacterial and viral. The study discusses meningitis and encephalitis caused by: $N$. meningitidis, S. pneumoniae, H. influenzae and tick-borne encephalitis virus. This is due to the epidemiological surveillance of these diseases and the available prevention in the form of vaccinations against these diseases.

AIM OF THE STUDY. The aim of the study is to assess the epidemiological situation of meningitis and encephalitis in Poland in 2018.

MATERIAL AND METHODS. The epidemiological situation of meningitis and encephalitis in Poland was assessed on data from the annual bulletin "Infectious diseases and poisoning in Poland in 2018" and "Vaccinations in Poland in 2018".

RESULTS. In 2018, a total of 2406 cases of meningitis and/or encephalitis were registered in Poland. It is a $14.7 \%$ increase in incidence compared to 2017. An increase was recorded in the viral infections from 1212 to 1533 cases. In contrast, the number of infections with bacterial etiology decreased from 886 to 873 cases. Meningitis and/or encephalitis caused by pathogens specified in epidemiological surveillance have noticed a decreased incidence. The only exception is the increase in cases caused by $S$. pneumoniae, compared to 2017, from 177 to 212. This is an increase of $19.8 \%$ compared to the previous year. However, the number of cases of $N$. meningitidis showed a decrease of $16.4 \%$ during this period. Viral infections constituted $63.7 \%$ of all cases. Compared to 2017, it means an increase in the percentage of viral infections by 5.9 percentage points.

Among laboratory confirmed cases of meningitis and/or encephalitis of known etiology, cases caused by Neisseria meningitidis (102 cases), Streptococcus pneumoniae (212 cases) and tick-borne encephalitis (197 cases) were predominant.

SUMMARY AND CONCLUSION. There is a general increasing trend in the number of cases of viral meningitis and/or encephalitis. On the other hand, thanks to vaccinations, no significant increase was noted in $H$. influenzae, meningococcal and TBE infections. There is a chance to minimize the incidence of bacterial meningitis and/or encephalitis as in the H. influenzae infections. On the other hand, it should be seen that the problem of diagnosing cases of viral etiology should be considered. This is more related to the determination of the etiological factor than the diagnosis of viral meningitis and/or encephalitis. Difficulties in determining the etiological factor indicate that, meningitis and/or encephalitis remain a challenge for healthcare and epidemiological surveillance institutions.
\end{abstract}

Key words: meningitis, encephalitis, epidemiology, Poland, 2018

* The work was carried out as part of task No. BE-1/2019. / Praca została wykonana w ramach zadania nr BE-1/2019

(C) National Institute of Public Health - National Institute of Hygiene / Narodowy Instytut Zdrowia Publicznego - Państwowy Zakład Higieny 


\section{STRESZCZENIE}

WSTĘP. Choroby zakaźne układu nerwowego najczęściej występują pod postacią zapalenia opon mózgowordzeniowych. Wyróżniamy zapalenia opon i /lub mózgu zgodnie z ich etiologią tj. bakteryjne i wirusowe. W opracowaniu omówiono zapalenia opon i/lub mózgu wywołane przez: $N$. meningitidis, S. pneumoniae, $H$. influenzae oraz wirus kleszczowego zapalenia mózgu. Wynika to z prowadzenia nadzoru epidemiologicznego nad tymi chorobami oraz dostępnej profilaktyki w postaci szczepień przeciw tym groźnym chorobom.

CEL PRACY. Celem pracy była ocena epidemiologiczna występowania zachorowań na zapalenie opon mózgowo-rdzeniowych i zapalenia mózgu w Polsce w 2018 r.

MATERIAL I METODY. Do przeprowadzenia analizy epidemiologicznej występowania zapalenia opon mózgowo-rdzeniowych i zapaleń mózgu wykorzystano dane nadsyłane do NIZP-PZH przez Wojewódzkie Stacje Sanitarno-Epidemiologiczne i publikowane w biuletynach rocznych: „Choroby zakaźne i zatrucia w Polsce” oraz „Szczepienia ochronne w Polsce”.

WYNIKI. W roku 2018 w Polsce zarejestrowano ogółem 2406 zachorowań na zapalenie opon mózgowordzeniowych i/lub zapalenie mózgu. Jest to wzrost zachorowań o ok. 14,7\% w porównaniu do roku 2017. Wzrost zanotowano głównie w przypadku infekcji o etiologii wirusowej: z 1212 do 1533 przypadków. Natomiast spadła liczba infekcji o etiologii bakteryjnej z 886 do 873 przypadków. Jedynym wyjątkiem jest wzrost liczby przypadków ze 177 do 212 zachorowań wywołanych przez S. pneumoniae w porównaniu do roku 2017. Jest to wzrost o $19,8 \%$ w stosunku do roku poprzedniego. Natomiast liczba zachorowań o etiologii $N$. meningitidis spadła o 16,4\%. Spośród wszystkich zarejestrowanych zachorowań $63,7 \%$ stanowiły infekcje o etiologii wirusowej. W porównaniu do roku 2017 jest to wzrost procentowego udziału infekcji wirusowych o 5,9 punktu procentowego. Wśród laboratoryjnie potwierdzonych przypadków zapaleń opon mózgowo-rdzeniowych i/lub zapaleń mózgu o ustalonej etiologii, dominują zachorowania wywołane przez Neisseria meningitidis (102 zachorowania), Streptococcus pneumoniae (212 zachorowań) oraz kleszczowe zapalenie mózgu (197 zachorowań).

PODSUMOWANIE I WNIOSKI. Zaobserwowano ogólną tendencję wzrostową zachorowań na wirusowe zapalenia opon i/lub mózgu. Natomiast dzięki szczepieniom, nie zanotowano wzrostu zakażeń $H$. influenzae, meningokokowych oraz KZM. Zaznaczyła się tendencja zmniejszenia zachorowań na zapalenia opon i /lub mózgu o etiologii bakteryjnej, również w przypadku H. influenzae. Jednak z drugiej strony zaobserwowano, że nadal utrzymuje się problemem wykonawstwa szczegółowej diagnostyki zachorowań o etiologii wirusowej tzn. diagnostyki z określeniem czynnika etiologicznego. Niedostateczne wykonawstwo badań z określeniem czynnika etiologicznego świadczy, że nadal zapalenia opon i/lub mózgu stanowią wyzwanie dla opieki zdrowotnej oraz instytucji nadzoru epidemiologicznego.

\section{Słowa kluczowe: zapalenie opon mózgowo-rdzeniowych, zapalenie mózgu, epidemiologia, Polska, rok 2018}

\section{INTRODUCTION}

We distinguish bacterial or viral etiology of meningitis and/or encephalitis. Bacterial meningitis and/or encephalitis are characterized by very high morbidity and mortality in children. This is especially noticeable in poorer countries. Most often these cases are caused by $N$. meningitidis, $S$. pneumoniae and $H$. influenzae (1).

For meningitis and/or encephalitis with viral etiology, tick-borne encephalitis virus is the main etiological factor. The share of TBE virus in central nervous system infections is the largest among viral encephalitis in Europe. In Poland, this problem mainly concerns the eastern part of the country. The most cases and the highest incidence occur in Podlaskie voivodeship. Therefore, Podlaskie voivodeship has the best diagnostics in the direction of TBE. Infection usually occurs as a result of a tick bite. However, there are cases of infection through the consumption

\section{WSTĘP}

Zapalenia opon mózgowych i zapalenia mózgu są etiologii bakteryjnej lub wirusowej. Zakażenia bakteryjne opon mózgowych i mózgu charakteryzują się bardzo wysoką zachorowalnością oraz śmiertelnością wśród dzieci. Dotyczy to szczególnie biedniejszych krajów. Najczęściej są to zachorowania wywołane przez $N$. meningitidis, S. pneumoniae oraz $H$. influenzae (1).

W przypadku zapaleń opon mózgowo-rdzeniowych i/lub mózgu o etiologii wirusowej, głównym czynnikiem etiologicznym jest wirus kleszczowego zapalenia mózgu. Udział wirusa KZM w zakażeniach ośrodkowego układu nerwowego jest największy wśród wirusowych zapaleń mózgu w Europie. W Polsce problem ten dotyczy przede wszystkim wschodniej części kraju. Najwięcej przypadków oraz największa zapadalność występuje w województwie podlaskim. Województwo podlaskie posiada najlepszą diagnostykę 
of unpasteurized milk from an animal in the viremia phase, in particular raw goat milk (2).

Vaccines are used to combat meningitis and encephalitis. They are most popular against $N$. meningitidis, S. pneumoniae, $H$. influenzae and tickborne encephalitis. Three types of $N$. meningitidis vaccines were available and used in Poland: monovalent $\mathrm{C}$, monovalent $\mathrm{B}$, quaternary $\mathrm{A}+\mathrm{C}+$ $\mathrm{Y}+\mathrm{W} 135$ and unconfigured (polysaccharide) A, C. According to the Protective Vaccination Program in 2018, meningococcal vaccinations are recommended and can be used in children from 2 months of age (3). Vaccination against $S$. pneumoniae was compulsory for children from 2 months of age. up to 5 years of age from high-risk groups with specific health indications. It was also recommended for adults from risk groups, people over 65 years of age. and children up to 5 years of age from risk groups other than those listed for compulsory vaccinations (3).

Vaccination against $H$. influenzae type $\mathrm{B}$ is compulsory for children from 2 months of age in fourdose scheme, and in case older children: from 6 months of age to twelve months of age in two-dose scheme, and in case children above 1 year of age should be vaccinated with one dose. In addition, vaccination is recommended for children up to 6 years of age who have not been vaccinated so far under compulsory vaccinations and for children who are particularly exposed to infection. given. and for children up to 6 years of age who are particularly exposed to infection (3).

In addition, the Ministry of Health recommended vaccinations against TBE ( 3 basic doses and reminders every 3-5 years) for people staying temporarily or permanently in areas with high prevalence of the disease (3).

\section{AIM OF THE STUDY}

The aim of the study is to assess the epidemiological situation of meningitis and encephalitis in Poland in 2018 .

\section{MATERIAL AND METHODS}

To carry out comparative analysis and epidemiological assessment of the occurrence of meningitis and/or encephalitis, data sent to NIPHNIH by voivodeship sanitary-epidemiological stations and published in annual bulletins and individual epidemiological interviews from the electronic Epidemiological Interview Recording System were used $(3,4)$.

Classification of infections was made on the basis of definitions of infectious disease cases developed w kierunku KZM. Do zakażenia dochodzi najczęściej w następstwie ukłucia przez kleszcza. Jednak zdarzają się przypadki zakażenia poprzez spożycie niepasteryzowanego mleka od zwierzęcia będącego w fazie wiremii, w szczególności surowego mleka koziego (2).

W celu zwalczania zapaleń opon mózgowych oraz zapaleń mózgu stosowane są szczepionki przeciw chorobom wywołanym przez $N$. meningitidis, $S$. pneumoniae, $H$. influenzae oraz kleszczowemu zapaleniu mózgu. W Polsce dostępne i stosowane były trzy rodzaje szczepionek przeciw $N$. meningitidis: monowalentna $\mathrm{C}$, monowalentna $\mathrm{B}$, czterowalentna $\mathrm{A}+\mathrm{C}+\mathrm{Y}+\mathrm{W} 135$ oraz polisacharydowa A, C. Zgodnie z Programem Szczepień Ochronnych w 2018 r. szczepienia przeciw meningokokom są zalecane i mogą być stosowane od 2 m.ż. (3). Szczepienie przeciw S. pneumoniae należy do szczepień obowiązkowych, począwszy od 2017 r., a ponadto jest realizowane u dzieci od $2 \mathrm{~m} . \dot{z}$. do 5 r.ż. z grup podwyższonego ryzyka ze szczególnymi wskazaniami zdrowotnymi. Również było (i nadal jest) zalecane osobom dorosłym $\mathrm{z}$ grup ryzyka, osobom powyżej 65 r.ż. oraz dzieciom do 5 r.ż. z grup ryzyka innych niż wymienione dla szczepień obowiązkowych (3).

Szczepienie przeciw $H$. influenzae typu B jest obowiązkowe dla dzieci od $2 \mathrm{~m} . \dot{z}$. w schemacie czterodawkowym, w przypadku dzieci od $6 \mathrm{~m} . \dot{z}$. do $12 \mathrm{~m} . \dot{z}$. w schemacie dwudawkowym, a w przypadku dzieci starszych tzn. powyżej jednego roku życia należy podać jedną dawkę szczepionki. Ponadto szczepienie jest zalecane dzieciom do 6 roku życia nieszczepionych dotychczas $w$ ramach szczepień obowiązkowych oraz dzieciom które są narażone w sposób szczególny na zakażenie (3).

Dodatkowo, Ministerstwo Zdrowia zalecało szczepienia przeciw KZM (3 dawki podstawowe oraz dawki przypominając co 3-5 lat) osobom przebywającym czasowo lub stale na terenach o nasilonym występowaniu choroby (3).

\section{CEL PRACY}

Celem pracy jest ocena epidemiologiczna występowania zachorowań na zapalenie opon mózgowo-rdzeniowych oraz zapalenia mózgu w Polsce w 2018 r.

\section{MATERIAŁ I METODY}

Do oceny epidemiologicznej występowania zapalenia opon mózgowo-rdzeniowych i/lub zapalenia mózgu wykorzystano dane nadsyłane do NIZP-PZH przez Wojewódzkie Stacje Sanitarno-Epidemiologiczne i publikowane w biuletynach rocznych oraz jednostkowe wywiady epidemiologiczne z elektronicznego Systemu Rejestracji Wywiadów Epidemiologicznych 
for the needs of epidemiological surveillance (version in force in 2018, Department of Epidemiology of Infectious Disease and Surveillance, NIPH-NIH). Case definitions were used for: $N$. meningitidis, $S$. pneumoniae, H. influenzae and tick-borne encephalitis. The analysis of the vaccination status against selected diseases took into account the recommendations of the "Protective Vaccination Program for 2018" (Annex to the Communication of the Chief Sanitary Inspector of October 31, 2017).

\section{RESULTS}

\section{BACTERIAL MENINGITIS AND ENCEPHALITIS}

In 2018; 873 cases of bacterial meningitis and/or encephalitis were registered in Poland (Table I), this is a similar number of cases to the previous year, taking into account similar incidence (about 2.3 per 100,000). The highest incidence was recorded in the Mazowieckie voivodeship - 108 (incidence of 2 per 100,000), the least in Lubuskie and Opolskie voivodeships - 24 cases each (incidence of 2.36 per 100,000 Lubuskie voivodeship, 2.43 per 100,000 Opolskie voivodeship). The situation is different in incidence rate. The highest incidence was recorded in Pomorskie voivodeship - 3.52 per 100,000 , the lowest in the Małopolskie voivodeship 1.44 per 100,000 population. Compared to 2017 , there are similarities where there were the most/least cases and where the highest incidence was recorded (Table VIII).

Similarly to 2017, in 2018 the incidence among men was higher than among women. Of the listed etiological factors, the largest difference was in pneumococcal infections (0.68 per 100,000 for men and 0.43 per 100,000 for women). Incidence by age did not differ much from last year, only significant decreases in meningococcal and pneumococcal infections were noted among women. However, as regards the incidence by place of residence, there was an increase in the incidence of pneumococcal infections in urban areas (from 0.44 to 0.61 per 100,000) and a decrease in other meningitis and/or encephalitis in rural areas (from 1.01 to 0.86 per 100,000 ) (Table III).

Meningitis and/or encephalitis caused by bacteria of known etiology most often affects young people under 24 years of age, only Haemophilus influenzae infection more often affected people over 24 years of age. Whereas the most exposed to bacterial meningitis and/or encephalitis in general are children under 4 years of age. (almost $21 \%$ of all cases of non-reported infections in other diseases) and people in the 45-64 age group (29\% of all cases). The highest number of cases of $N$. meningitidis infections was observed
$(3,4)$. Klasyfikacji zakażeń dokonano w oparciu o definicje przypadków chorób zakaźnych opracowane na potrzeby nadzoru epidemiologicznego (wersja obowiązująca w roku 2018, Zakład Epidemiologii Chorób Zakaźnych i Nadzoru, NIZP-PZH).

Definicje przypadków zastosowano dla: $N$. meningitidis, S. pneumoniae, $H$. influenzae oraz kleszczowego zapaleniu mózgu. Analiza stanu zaszczepienia przeciw wybranym chorobom uwzględniała zalecenia „Programu Szczepień Ochronnych na rok 2018” (Załącznik do Komunikatu Głównego Inspektora Sanitarnego z dn. 31 października 2017 r.).

\section{WYNIKI}

\section{ZAPALENIE OPON MÓZGOWO- RDZENIOWYCH I ZAPALENIE MÓZGU O ETIOLOGII BAKTERYJNEJ}

W roku 2018 w Polsce zarejestrowano 873 zachorowania na zapalenie opon mózgowo-rdzeniowych i/ lub mózgu o etiologii bakteryjnej (Tab. I). Jest to porównywalna liczba przypadków do roku poprzedniego, biorąc pod uwagę zbliżoną zapadalność (ok. 2,3 na 100 tys.). Najwięcej zachorowań zanotowano w województwie mazowieckim - 108 (zapadalność 2 na 100 tys.), najmniej w województwach lubuskim i opolskim - po 24 przypadki (zapadalność 2,36 na 100 tys. województwo lubuskie; 2,43 na 100 tys. województwo opolskie). Natomiast pod względem zapadalności dominowało województwo pomorskie- 3,52 na 100 tys., a najniższa zapadalność wystąpiła w województwie małopolskim - 1,44 na 100 tysięcy osób. Sytuacja dotycząca zarówno liczby zachorowań jak i zapadalności w porównaniu do roku 2017 jest porównywalna (Tab. VIII).

Podobnie do roku 2017, w roku 2018 zapadalność wśród mężczyzn była wyższa niż u kobiet. Spośród omawianych czynników etiologicznych, największa różnica dotyczyła zakażeń pneumokokowych: 0,68 na 100 tys. dla mężczyzn oraz 0,43 na 100 tys. dla kobiet. Zapadalność wg wieku nie różniła się zasadniczo od zeszłorocznej, jedynie zanotowano znaczne spadki zakażeń meningokokowych oraz pneumokokowych wśród kobiet. Natomiast zapadalność wg miejsca zamieszkania wskazuje na jej wzrost w wyniku zakażeń pneumokokowych w obszarach miejskich (z 0,44 do 0,61 na 100 tys.) oraz spadek innych zapaleń opon mózgowo-rdzeniowych i/lub mózgu na obszarach wiejskich (z 1,01 do 0,86 na 100 tys.) (Tab. III).

Zapalenie opon mózgowych i/lub mózgu wywołane przez bakterie o znanej etiologii najczęściej dotyczy osób młodych do 24 roku życia, jedynie zakażenia Haemophilus influenzae częściej dotyczyło osób od 25 roku życia. Natomiast najbardziej narażoną na bakte- 


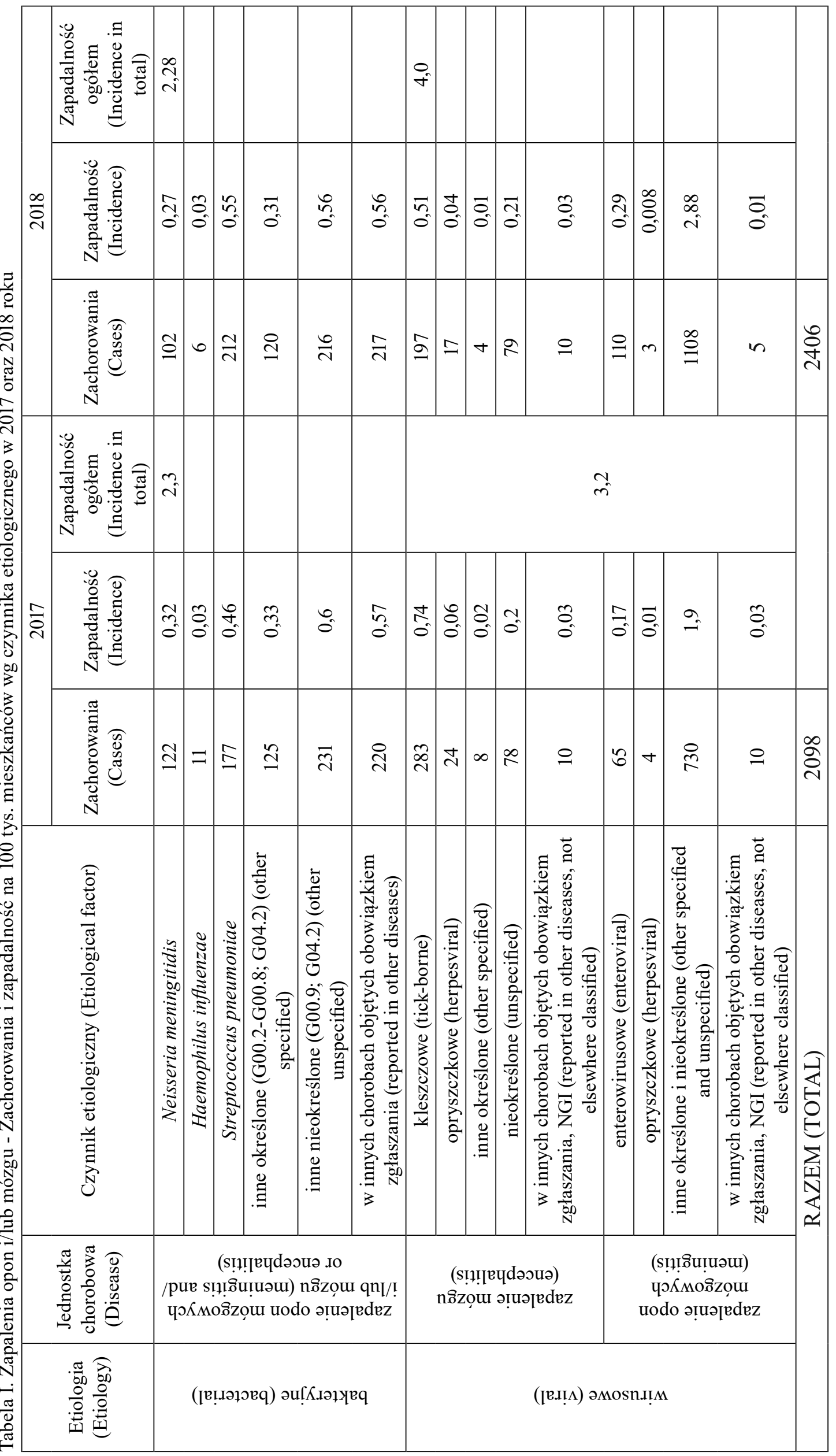


Table II. Bacterial meningitis and/or encephalitis. Number of cases and incidence per 100000 population by etiological agent in 2017 and 2018

Tabela II. Bakteryjne zapalenia opon i/lub mózgu - Zachorowania i zapadalność na 100 tys. mieszkańców wg czynnika etiologicznego w 2017 oraz 2018 roku

\begin{tabular}{|c|c|c|c|c|c|}
\hline \multirow{2}{*}{$\begin{array}{c}\text { Jednostka } \\
\text { chorobowa } \\
\text { (Disease) }\end{array}$} & $\begin{array}{c}\text { Czynnik } \\
\text { etiologiczny } \\
\text { (Etiological } \\
\text { factor) }\end{array}$ & $\begin{array}{c}\text { Zachorowania } \\
\text { (Cases) }\end{array}$ & $\begin{array}{c}\text { Zapadalność } \\
\text { (Incidence) }\end{array}$ & $\begin{array}{c}\text { Zachorowania } \\
\text { (Cases) }\end{array}$ & $\begin{array}{c}\text { Zapadalność } \\
\text { (Incidence) }\end{array}$ \\
\cline { 3 - 6 } & $\begin{array}{c}\text { Neisseria } \\
\text { meningitidis }\end{array}$ & 122 & 0,32 & 102 & 0,27 \\
\cline { 2 - 6 } & $\begin{array}{c}\text { Haemophilus } \\
\text { influenzae }\end{array}$ & 11 & 0,03 & 6 & 0,03 \\
\cline { 2 - 6 } & $\begin{array}{c}\text { Streptococcus } \\
\text { pneumoniae }\end{array}$ & 177 & 0,46 & 212 & 0,55 \\
\cline { 2 - 6 } \\
\cline { 2 - 6 } \\
$\begin{array}{c}\text { inne określone } \\
\text { (G00.2-G00.8; } \\
\text { G04.2) (other } \\
\text { specified) }\end{array}$
\end{tabular}

among children under 4 years of age. The number of $S$. pneumoniae infections was higher in people over 25 years of age, however, the highest incidence was in children under 4 years of age (Table IV).

In the group of 873 cases of bacterial meningitis and/ or encephalitis for $320(36.7 \%)$ the etiological factor was one of three pathogens: Neisseria meningitidis, Streptococcus pneumoniae, and Haemophilus influenzae (Table I). In this group, meningococcal and pneumococcal infections accounted for $98.1 \%$.

Among children and adolescents up to 19 years of age, as in 2017, cases of $N$. meningitidis were predominant (61 cases, $60 \%$ of all meningococcal infections). In contrast, $85.8 \%$ of $S$. pneumoniae infections were registered in people over 24 years of age (182 cases). The highest incidence of bacterial meningitis and/or encephalitis among children and adolescents up to 19 years of age. can be seen in the group of children up to 4 years of age regardless of the etiology (Table IV).

Neisseria meningitidis. The number of cases and the incidence of meningitis and/or encephalitis caused by $N$. meningitidis recorded in 2018 was 102 (incidence 0.27 per 100,000 ), which means a decrease compared to 2017 - 122 cases (incidence 0.32 per 100,000) (Table ryjne zapalenia opon mózgowych i/lub mózgu ogółem są dzieci do 4 r.ż. (prawie 21\% wszystkich zgłoszonych zakażeń) oraz osoby w grupie wieku 45-64 lata (29\% wszystkich przypadków). Największą liczbę zakażeń wywołanych $N$. meningitidis zaobserwowano wśród dzieci do 4 roku życia. Liczba zakażeń o etiologii $S$. pneumoniae była większa u osób powyżej 25 roku życia, jednak najwyższa zapadalność dotyczyła dzieci do lat 4 (Tab. IV).

W grupie 873 przypadków bakteryjnego zapalenia opon mózgowo-rdzeniowych i/lub zapalenia mózgu u 320 (36,7\%) czynnikiem etiologicznym był jeden z trzech drobnoustrojów: Neisseria meningitidis, Streptococcus pneumoniae, Haemophilus influenzae (Tab. I). W tej grupie zakażenia meningokokowe i pneumokokowe stanowiły $98,1 \%$.

Wśród dzieci i młodzieży do 19 r.ż., podobnie jak w roku 2017, dominowały zachorowania o etiologii $N$. meningitidis (61 zachorowań, 60\% ogółu zakażeń meningokokowych). Natomiast u osób powyżej 24 roku życia zarejestrowano $85,8 \%$ zakażeń o etiologii $S$. pneumoniae (182 zachorowania). Najwyższą zapadalność na bakteryjne zapalenia opon i/lub mózgu wśród dzieci i młodzieży do 19 r.ż. można zaobserwować 


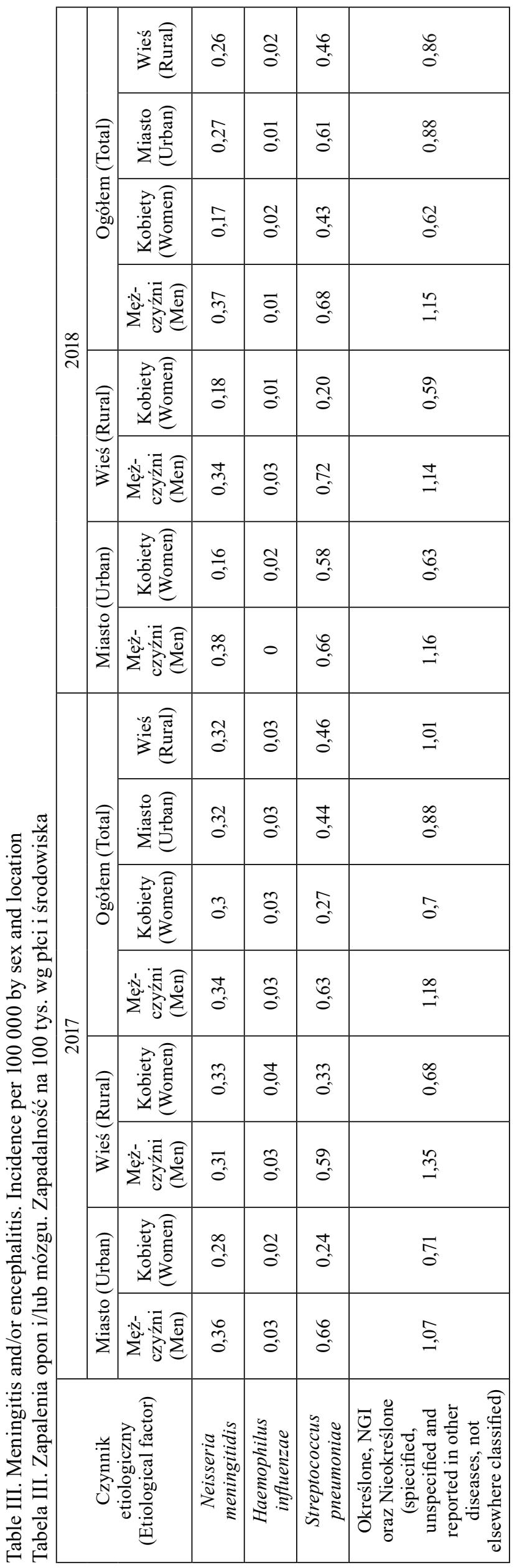

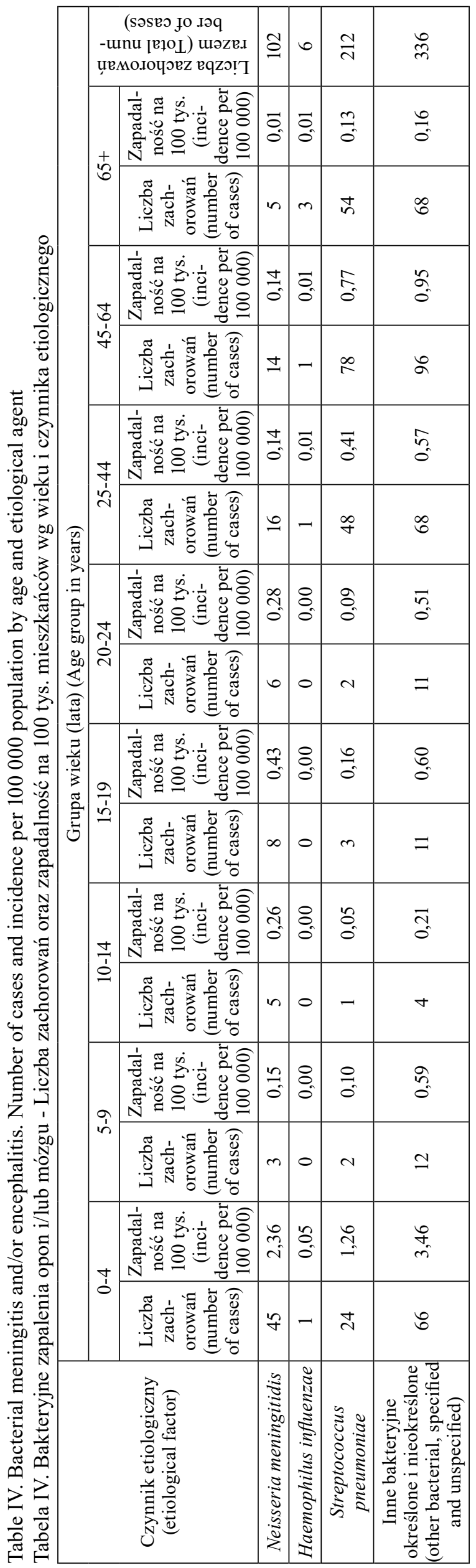


I). Meningitis and/or encephalitis of the etiology of $N$. meningitidis mainly affects children under 4 years of age, the highest incidence $(2.36$ per 100,000$)$ was observed in this age group.

In addition, the number of cases in children under 4 years of age is $44 \%$ of all meningococcal infections in 2018 (Table IV).

Meningococcal infections have been more commonly reported in men, regardless to the place of residence. On the other hand, the incidence is similar in urban and rural areas $(0.27$ per 100,000 - urban area, 0.26 per 100,000 - rural area), as in 2017 (0.32 per 100,000 for urban and rural areas) (Table III).

The highest incidence was recorded in Zachodniopomorskie voivodeship (0.7 per 100,000$)$, and the largest number of cases was recorded in Wielkopolskie voivodeship (15 cases). Whereas the smallest incidence rate was recorded in Podlaskie voivodeship (0.08 per 100,000), and the smallest number of cases was in the Podlaskie and Opolskie voivodeships (one case each). Comparing to the previous year, cases occurred in each voivodeship, however, the number of cases and the incidence in individual voivodeships was lower. The situation was identical to the previous year only in Podlaskie voivodeship. Comparing incidence in quarters, in 2018, just like in 2017, the largest number of cases was in Q1 (34\% of all cases), but there was a decrease in cases in Q3 (Table V).

In 2018, the number of people vaccinated against $N$. meningitidis were 98223 people, i.e. $75.9 \%$ more than in 2017 (55 847 people). $92 \%$ of all vaccinated persons were children and adolescents up to 19 years of age.

Haemophilus influenzae typu B. The number of meningitis and/or encephalitis cases caused by $H$. influenzae type B remains low - in 2018 there were 6 cases. Despite the decrease in incidence, the incidence remains at the same level as in 2017 (incidence of 0.03 per 100,000) (Table I). In 2018, cases were recorded in 4 voivodeships. The highest number of cases occurred in Mazowieckie voivodeship - 3 (incidence 0.06 per $100,000)$, i.e. half of all cases. A total of 5 cases $(83.3 \%)$ of people over 34 years of age were reported, of whom $60 \%$ were rural residents. There was one case in the age group $0-4$ years (incidence -0.05 per 100,000).

In 2018, the vaccination status of 2-year-olds (primary vaccination) against $H$. influenzae in individual voivodeships ranged from $91.1 \%$ in Podlaskie voivodeship to $98.4 \%$ in WarmińskoMazurskie voivodeship. For comparison, the average vaccination status for Poland was $95.4 \%$.

Streptococcus pneumoniae. In 2018, a total of 212 cases (incidence 0.55 per 100,000 ) of meningitis and/or encephalitis caused by $S$. pneumoniae were registered in Poland (Table 1). This is an increase w grupie dzieci do 4 r.ż. niezależnie od etiologii (Tab. IV).

Neisseria meningitidis. Zachorowania i zapadalność na meningokokowe zapalenie opon mózgowo-rdzeniowych i/lub mózgu zarejestrowane w 2018 roku wyniosły odpowiednio: 102 i 0,27 na 100 tys., co oznacza spadek w porównaniu do roku 2017, w którym wystąpiły - 122 zachorowania $\mathrm{z}$ zapadalnością 0,32 na 100 tys. (Tab. I). Zapalenie opon mózgowo-rdzeniowych i/lub mózgu o etiologii $N$. meningitidis dotyczy głównie dzieci do 4 r.ż., właśnie w tej grupie wieku zaobserwowano najwyższą zapadalność $(2,36$ na 100 tys.). Dodatkowo liczba przypadków u dzieci do 4 r.ż. wynosi $44 \%$ wszystkich przypadków zakażeń meningokokowych w 2018 roku (Tab. IV).

Zakażenia meningokokowe zanotowano częściej u mężczyzn niezależnie od miejsca zamieszkania. Natomiast zapadalność zarówno w mieście jak i na wsi jest porównywalna: 0,27 na 100 tys. - miasto; 0,26 na 100 tys. - wieś, podobnie jak w 2017 roku $(0,32$ na 100 tys. zarówno dla miasta jak i wsi) (Tab. III). Najwyższą zapadalność zarejestrowano w województwie zachodniopomorskim (0,7 na 100 tys.), a największa liczba przypadków została odnotowana w województwie wielkopolskim (15 przypadków). Natomiast najniższy współczynnik zapadalności zarejestrowano w województwie podlaskim ( 0,08 na 100 tys.), a najmniejsza liczba przypadków była w województwie podlaskim i opolskim (po jednym przypadku). Porównując do poprzedniego roku, zachorowania wystąpiły w każdym województwie, jednak liczba przypadków i zapadalność w poszczególnych województwach była niższa. Taką samą sytuację zaobserwowano w roku poprzednim jedynie $\mathrm{w}$ województwie podlaskim. Porównując zachorowalność w kwartałach zaobserwowano, że w 2018 podobnie jak w 2017, najwięcej zachorowań wystąpiło w I kwartale (34\% wszystkich przypadków), ale nastąpił znaczy spadek przypadków w III kwartale (Tab. V).

W 2018 r. liczba zaszczepionych osób przeciw $N$. meningitidis wyniosła 98223 osób, tj. o 75,9\% więcej niż w roku 2017 (55 847 osób). 92\% ogółu zaszczepionych stanowiły dzieci i młodzież do 19 r.ż.

Haemophilus influenzae typu B. Liczba zachorowań na zapalenie opon mózgowych i/lub mózgu wywołane przez $H$. influenzae typu B utrzymuje się na niskim poziomie - w 2018 r. wystąpiło 6 zachorowań. Pomimo spadku zachorowań, zapadalność pozostaje na takim samym poziomie jak w roku $2017 \mathrm{tj} .0,03 \mathrm{na}$ 100 tys. (Tab. I). W 2018 r. zachorowania zarejestrowano w 4 województwach. Najwięcej zachorowań wystąpiło w województwie mazowieckim - 3 (zapadalność 0,06 na 100 tys.), czyli połowa wszystkich przypadków. Zgłoszono ogółem 5 zachorowań $(83,3 \%)$ u osób powyżej 34 r.ż., z których $60 \%$ stanowili mieszkańcy 
Table V. Meningococcal disease: meningitis and/or encephalitis. Number of cases and incidence per 100000 population by voivodeships in 2018

Tabela V. Choroba meningokokowa: Zapalenie opon mózgowych i/lub mózgu - Liczba zachorowań oraz zapadalność na 100 tys. mieszkańców wg województw w 2018 roku

\begin{tabular}{|c|c|c|c|c|c|c|c|}
\hline \multirow{2}{*}{\multicolumn{2}{|c|}{$\begin{array}{l}\text { Województwo } \\
\text { (Voivodeship) }\end{array}$}} & \multicolumn{4}{|c|}{$\begin{array}{c}\text { Liczba zachorowań w kwartałach (Number of cases in } \\
\text { quarters) }\end{array}$} & \multirow{2}{*}{$\begin{array}{c}\text { Liczba } \\
\text { zachorowań } \\
\text { w roku } \\
\text { (Number of } \\
\text { cases - total) }\end{array}$} & \multirow{2}{*}{$\begin{array}{c}\text { Zapadalność } \\
\text { na } 100 \text { tys. } \\
\text { (Incidence } \\
\text { per } 100000 \text { ) }\end{array}$} \\
\hline & & I & II & III & IV & & \\
\hline \multirow{2}{*}{$\begin{array}{l}\text { Polska } \\
\text { (Poland) }\end{array}$} & $2017 \mathrm{r}$. & 39 & 31 & 23 & 29 & 122 & 0,32 \\
\hline & $2018 \mathrm{r}$. & 35 & 26 & 9 & 32 & 102 & 0,27 \\
\hline \multicolumn{2}{|c|}{ Dolnośląskie } & 1 & 3 & 3 & 0 & 7 & 0,24 \\
\hline \multicolumn{2}{|c|}{ Kujawsko-Pomorskie } & 1 & 0 & 0 & 2 & 3 & 0,14 \\
\hline \multicolumn{2}{|c|}{ Lubelskie } & 1 & 0 & 1 & 1 & 3 & 0,14 \\
\hline \multicolumn{2}{|c|}{ Lubuskie } & 1 & 1 & 0 & 0 & 2 & 0,20 \\
\hline \multicolumn{2}{|c|}{ Łódzkie } & 1 & 1 & 0 & 2 & 4 & 0,16 \\
\hline \multicolumn{2}{|c|}{ Małopolskie } & 1 & 4 & 0 & 1 & 6 & 0,18 \\
\hline \multicolumn{2}{|c|}{ Mazowieckie } & 5 & 2 & 2 & 4 & 13 & 0,24 \\
\hline \multicolumn{2}{|c|}{ Opolskie } & 0 & 1 & 0 & 0 & 1 & 0,10 \\
\hline \multicolumn{2}{|c|}{ Podkarpackie } & 2 & 2 & 0 & 2 & 6 & 0,28 \\
\hline \multicolumn{2}{|c|}{ Podlaskie } & 1 & 0 & 0 & 0 & 1 & 0,08 \\
\hline \multicolumn{2}{|c|}{ Pomorskie } & 4 & 4 & 0 & 2 & 10 & 0,43 \\
\hline \multicolumn{2}{|c|}{ Śląskie } & 6 & 0 & 2 & 3 & 11 & 0,24 \\
\hline \multicolumn{2}{|c|}{ Świętokrzyskie } & 3 & 0 & 0 & 0 & 3 & 0,24 \\
\hline \multicolumn{2}{|c|}{ Warmińsko-Mazurskie } & 1 & 0 & 0 & 4 & 5 & 0,35 \\
\hline \multicolumn{2}{|c|}{ Wielkopolskie } & 5 & 4 & 0 & 6 & 15 & 0,43 \\
\hline \multicolumn{2}{|c|}{ Zachodniopomorskie } & 2 & 4 & 1 & 5 & 12 & 0,70 \\
\hline
\end{tabular}

in the number of cases by almost $24 \%$ compared to 2017. The most cases, i.e. 25, were registered in Mazowieckie voivodeship (11.8\%), the least in Warmińsko-Mazurskie voivodeship (7 cases). On the other hand, the highest incidence was recorded in Zachodniopomorskie voivodeship - 1.06 per 100,000 , and the lowest in Podlaskie voivodeship 0.17 per 100,000 (Table VI). The incidence of meningitis and/ or encephalitis caused by $S$. pneumoniae was higher in urban than in rural areas ( 0.61 per 100,000 in urban area and 0.46 per 100,000 in rural area). Increase of incidence occurred in urban areas, while in rural areas it remained at the level from last year (Table III). $84.9 \%$ of cases occurred in people over 24 years of age, in this group the most represented were people in age group 45-64 (36.8\% of all cases caused by $S$. pneumoniae) (Table IV). This is a similar percentage of cases in these age groups as in 2017. The increase in the share of cases of children in age group 0-4 years compared to 2017 is worth to note. In this age group, the incidence accounted for $11.3 \%$; whereas the incidence totaled 1.26 per 100,000 .

In 2018, 188,291 people were vaccinated against $S$. pneumoniae, which is an increase of $1.3 \%$ compared to $2017.87 \%$ of those vaccinated are children up to 4 wsi. W grupie wieku 0-4 lata wystąpiło jedno zachorowanie (zapadalność - 0,05 na 100 tys.).

W 2018 r. stan zaszczepienia 2-latków (szczepienie pierwotne) przeciw $H$. influenzae w poszczególnych województwach zawierał się w przedziale od $91,1 \%$ w województwie podlaskim do $98,4 \%$ w województwie warmińsko-mazurskim. Natomiast ogółem stan zaszczepienia dla Polski wyniósł 95,4\%.

Streptococcus pneumoniae. W 2018 r. zarejestrowano w Polsce ogółem 212 zachorowań (zapadalność 0,55 na 100 tys.) na zapalenie opon mózgowo-rdzeniowych i/lub mózgu wywołanych przez $S$. pneumoniae (Tab. I). Jest to wzrost przypadków o prawie $24 \%$ względem roku 2017. Najwięcej przypadków, tj. 25, zarejestrowano w województwie mazowieckim $(11,8 \%)$, najmniej w województwie warmińsko-mazurskim (7 przypadków). Natomiast najwyższą zapadalność zanotowano $\mathrm{w}$ województwie zachodniopomorskim - 1,06 na 100 tys., a najniższą w województwie podlaskim 0,17 na 100 tys. (Tab. VI). Zapadalność na zapalenie opon mózgowo - rdzeniowych i/lub mózgu wywołane przez $S$. pneumoniae była wyższa w mieście niż na wsi $(0,61$ na 100 tys. na terenach miejskich oraz 0,46 na 100 tys. na obszarach wiejskich). Wzrost zapadalności wystąpił na obszarach miejskich, a na obszarach 
Table VI. Disease caused by S. pneumoniae: meningitis and/or encephalitis. Number of cases and incidence per 100000 population by voivodeships in 2018

Tabela VI. Choroba wywołana przez S. pneumoniae, inwazyjna: Zapalenie opon mózgowych i/lub mózgu - Liczba zachorowań oraz zapadalność na 100 tys. mieszkańców wg województw w 2018 roku

\begin{tabular}{|c|c|c|c|c|c|c|c|}
\hline \multirow{2}{*}{\multicolumn{2}{|c|}{$\begin{array}{l}\text { Województwo } \\
\text { (Voivodeship) }\end{array}$}} & \multicolumn{4}{|c|}{$\begin{array}{l}\text { Liczba zachorowań w kwartałach } \\
\text { (Number of cases in quarters) }\end{array}$} & \multirow{2}{*}{$\begin{array}{c}\text { Liczba } \\
\text { zachorowań } \\
\text { (Number of } \\
\text { cases ) }\end{array}$} & \multirow{2}{*}{$\begin{array}{c}\text { Zapadalność } \\
\text { na } 100 \text { tys. } \\
\text { (Incidence } \\
\text { per } 100000 \text { ) }\end{array}$} \\
\hline & & $\mathrm{I}$ & II & III & IV & & \\
\hline \multirow{2}{*}{$\begin{array}{l}\text { Polska } \\
\text { (Poland) }\end{array}$} & $2017 \mathrm{r}$. & 54 & 55 & 21 & 47 & 177 & 0,46 \\
\hline & $2018 \mathrm{r}$. & 68 & 60 & 35 & 49 & 212 & 0,55 \\
\hline \multicolumn{2}{|c|}{ Dolnośląskie } & 4 & 9 & 2 & 8 & 23 & 0,79 \\
\hline \multicolumn{2}{|c|}{ Kujawsko-Pomorskie } & 5 & 2 & 2 & 4 & 13 & 0,63 \\
\hline \multicolumn{2}{|c|}{ Lubelskie } & 2 & 4 & 1 & 3 & 10 & 0,47 \\
\hline \multicolumn{2}{|c|}{ Lubuskie } & 3 & 3 & 0 & 2 & 8 & 0,79 \\
\hline \multicolumn{2}{|c|}{ Łódzkie } & 9 & 2 & 1 & 3 & 15 & 0,61 \\
\hline \multicolumn{2}{|c|}{ Małopolskie } & 4 & 2 & 1 & 2 & 9 & 0,27 \\
\hline \multicolumn{2}{|c|}{ Mazowieckie } & 6 & 6 & 10 & 3 & 25 & 0,46 \\
\hline \multicolumn{2}{|c|}{ Opolskie } & 1 & 1 & 0 & 3 & 5 & 0,51 \\
\hline \multicolumn{2}{|c|}{ Podkarpackie } & 3 & 3 & 0 & 2 & 8 & 0,38 \\
\hline \multicolumn{2}{|c|}{ Podlaskie } & 0 & 1 & 1 & 0 & 2 & 0,17 \\
\hline \multicolumn{2}{|c|}{ Pomorskie } & 6 & 5 & 3 & 2 & 16 & 0,69 \\
\hline \multicolumn{2}{|c|}{ Śląskie } & 6 & 7 & 4 & 5 & 22 & 0,48 \\
\hline \multicolumn{2}{|c|}{ Świętokrzyskie } & 3 & 4 & 1 & 2 & 10 & 0,80 \\
\hline \multicolumn{2}{|c|}{ Warmińsko-Mazurskie } & 3 & 2 & 0 & 2 & 7 & 0,49 \\
\hline \multicolumn{2}{|c|}{ Wielkopolskie } & 7 & 4 & 5 & 5 & 21 & 0,60 \\
\hline \multicolumn{2}{|c|}{ Zachodniopomorskie } & 6 & 5 & 4 & 3 & 18 & 1,06 \\
\hline
\end{tabular}

years of age. In 2018, the highest percentage of people vaccinated against $S$. pneumoniae in Poland (15.1\%) were in Mazowieckie voivodeship.

\section{VIRAL MENINGITIS AND ENCEPHALITIS}

In 2018, a total of 1,533 cases of viral meningitis and/or encephalitis were recorded (incidence of 4 per $100,000)$, which is an increase of $26.5 \%$ compared to 2017. In this group, most often (72.3\%) other specified and unspecified viral meningitis was diagnosed (1108 cases; incidence of 2.88 per 100,000 ) (Table I).

Tick-borne encephalitis (TBE). In 2018, a total of 197 cases of tick-borne encephalitis (A84) were reported in 13 of 16 voivodeships (Table VII); incidence was 0.51 per 100,000. Compared to 2017, the number of cases and the incidence dropped; number of cases by $43.6 \%$ and incidence by $68.9 \%$. Most cases, as in previous years, were recorded in the north-eastern areas of Poland, in Podlaskie (37\% of all cases), Warmińsko-Mazurskie and Mazowieckie $(12.7 \%$ of all cases) voivodeships. The highest incidence of TBE was recorded in Podlaskie and Warmińsko-Mazurskie voivodeships; it was, respectively: 6.17 and 1.75 per 100,000 , which compared to the previous year is a significant decrease (by more than $50 \%$ ). In other wiejskich pozostał na poziomie z zeszłego roku (Tab. III). Ponad $3 / 4$ zachorowań tj. 84,9\% wystąpiło u osób powyżej 24 r.ż., w tej grupie najliczniej reprezentowane były osoby w wieku $45-64$ lata $(36,8 \%$ wszystkich zachorowań wywołanych przez S. pneumoniae) (Tab. IV). Jest on porównywalny z odsetkiem zachorowań w tych grupach wieku w 2017 roku. Warto podkreślić wzrost udziału zachorowań dzieci w wieku 0-4 lata w porównaniu do 2017 roku. W tej grupie wieku zachorowania stanowiły $11,3 \%$; zapadalność natomiast wyniosła ogółem 1,26 na 100 tys.

W 2018 r. - drugim roku obowiązkowych szczepień przeciw pneumokokom -zaszczepiono przeciw S. pneumoniae 188291 osób, co stanowi wzrost w stosunku do 2017 r. o 1,3\%. Natomiast $87 \%$ osób szczepionych stanowią dzieci do 4 r.ż. W 2018 roku najwyższy odsetek osób zaszczepionych przeciw $S$. pneumoniae w Polsce $(15,1 \%)$ przypada na województwo mazowieckie.

\section{ZAPALENIE OPON MÓZGOWO- RDZENIOWYCH I ZAPALENIE MÓZGU O ETIOLOGII WIRUSOWEJ}

W 2018 r. zarejestrowano ogółem 1533 przypadki zapaleń opon i/lub mózgu o etiologii wirusowej (za- 
Table VII. Tick-borne encephalitis. Number of cases and incidence per 100000 population by voivodeships in 2018 Tabela VII. Kleszczowe zapalenie mózgu. Liczba zachorowań oraz zapadalność na 100 tys. mieszkańców wg województw w 2018 roku

\begin{tabular}{|c|c|c|c|c|c|c|c|}
\hline \multirow{2}{*}{\multicolumn{2}{|c|}{$\begin{array}{l}\text { Województwo } \\
\text { (Voivodeship) }\end{array}$}} & \multicolumn{4}{|c|}{$\begin{array}{l}\text { Liczba zachorowań w kwartałach } \\
\text { (Number of cases in quarters) }\end{array}$} & \multirow{3}{*}{$\begin{array}{c}\begin{array}{c}\text { Liczba } \\
\text { zachorowan } \\
\text { (Number of } \\
\text { cases ) }\end{array} \\
283\end{array}$} & \multirow{3}{*}{$\begin{array}{c}\begin{array}{c}\text { Zapadalność } \\
\text { na } 100 \text { tys. } \\
\text { (Incidence }\end{array} \\
\text { per } 100000) \\
0,74\end{array}$} \\
\hline & & \multirow{2}{*}{$\begin{array}{l}\text { I } \\
8 \\
\end{array}$} & \multirow{2}{*}{$\begin{array}{l}\text { II } \\
33\end{array}$} & \multirow{2}{*}{$\begin{array}{c}\text { III } \\
101\end{array}$} & \multirow{2}{*}{$\begin{array}{c}\text { IV } \\
141 \\
\end{array}$} & & \\
\hline Polska & $2017 \mathrm{r}$. & & & & & & \\
\hline (Poland) & $2018 \mathrm{r}$. & 12 & 31 & 83 & 71 & 197 & 0,51 \\
\hline \multicolumn{2}{|c|}{ Dolnośląskie } & 2 & 1 & 10 & 5 & 18 & 0,62 \\
\hline \multicolumn{2}{|c|}{ Kujawsko-Pomorskie } & 0 & 0 & 0 & 0 & 0 & 0 \\
\hline \multicolumn{2}{|c|}{ Lubelskie } & 1 & 3 & 5 & 1 & 10 & 0,47 \\
\hline \multicolumn{2}{|c|}{ Lubuskie } & 0 & 0 & 0 & 0 & 0 & 0 \\
\hline \multicolumn{2}{|c|}{ Łódzkie } & 2 & 0 & 4 & 0 & 6 & 0,24 \\
\hline \multicolumn{2}{|c|}{ Małopolskie } & 0 & 0 & 7 & 10 & 17 & 0,50 \\
\hline \multicolumn{2}{|c|}{ Mazowieckie } & 2 & 4 & 5 & 14 & 25 & 0,46 \\
\hline \multicolumn{2}{|c|}{ Opolskie } & 0 & 2 & 5 & 1 & 8 & 0,81 \\
\hline \multicolumn{2}{|c|}{ Podkarpackie } & 0 & 0 & 0 & 2 & 2 & 0,09 \\
\hline \multicolumn{2}{|c|}{ Podlaskie } & 3 & 16 & 30 & 24 & 73 & 6,17 \\
\hline \multicolumn{2}{|c|}{ Pomorskie } & 0 & 0 & 0 & 0 & 0 & 0 \\
\hline \multicolumn{2}{|c|}{ Śląskie } & 0 & 0 & 0 & 2 & 2 & 0,04 \\
\hline \multicolumn{2}{|c|}{ Świętokrzyskie } & 1 & 1 & 4 & 3 & 9 & 0,72 \\
\hline \multicolumn{2}{|c|}{ Warmińsko-Mazurskie } & 1 & 4 & 12 & 8 & 25 & 1,75 \\
\hline \multicolumn{2}{|c|}{ Wielkopolskie } & 0 & 0 & 1 & 0 & 1 & 0,03 \\
\hline \multicolumn{2}{|c|}{ Zachodniopomorskie } & 0 & 0 & 0 & 1 & 1 & 0,06 \\
\hline
\end{tabular}

Table VIII. Bacterial meningitis and/or encephalitis. Number of cases and incidence per 100000 population by voivodeships in 2018

Tabela VIII. Bakteryjne zapalenie opon i/lub mózgu. Liczba zachorowań oraz zapadalność na 100 tys. mieszkańców wg województw w 2018 roku

\begin{tabular}{|c|c|c|c|c|c|c|c|}
\hline \multirow{2}{*}{\multicolumn{2}{|c|}{$\begin{array}{l}\text { Województwo } \\
\text { (Voivodeship) }\end{array}$}} & \multicolumn{4}{|c|}{$\begin{array}{c}\text { Liczba zachorowań w kwartałach } \\
\text { (Number of incident cases in quarters) }\end{array}$} & \multirow{3}{*}{$\begin{array}{c}\text { Liczba } \\
\text { zachorowań } \\
\text { (Number of } \\
\text { cases ) } \\
886\end{array}$} & \multirow{3}{*}{$\begin{array}{c}\text { Zapadalność } \\
\text { na } 100 \text { tys. } \\
\text { (Incidence } \\
\text { per } 100000 \text { ) } \\
2,31\end{array}$} \\
\hline & & \multirow{2}{*}{$\begin{array}{c}\mathrm{I} \\
235\end{array}$} & \multirow{2}{*}{$\begin{array}{c}\text { II } \\
197\end{array}$} & \multirow{2}{*}{$\begin{array}{c}\text { III } \\
208 \\
\end{array}$} & \multirow{2}{*}{$\begin{array}{c}\text { IV } \\
246\end{array}$} & & \\
\hline Polska & $2017 \mathrm{r}$. & & & & & & \\
\hline (Poland) & $2018 \mathrm{r}$. & 226 & 214 & 195 & 238 & 873 & 2,27 \\
\hline \multicolumn{2}{|c|}{ Dolnośląskie } & 10 & 23 & 15 & 23 & 71 & 2,45 \\
\hline \multicolumn{2}{|c|}{ Kujawsko-Pomorskie } & 8 & 12 & 7 & 11 & 38 & 1,83 \\
\hline \multicolumn{2}{|c|}{ Lubelskie } & 7 & 10 & 7 & 12 & 36 & 1,70 \\
\hline \multicolumn{2}{|c|}{ Lubuskie } & 5 & 6 & 8 & 5 & 24 & 2,36 \\
\hline \multicolumn{2}{|c|}{ Łódzkie } & 19 & 6 & 12 & 14 & 51 & 2,06 \\
\hline \multicolumn{2}{|c|}{ Małopolskie } & 11 & 13 & 14 & 11 & 49 & 1,44 \\
\hline \multicolumn{2}{|c|}{ Mazowieckie } & 39 & 27 & 22 & 20 & 108 & 2,00 \\
\hline \multicolumn{2}{|c|}{ Opolskie } & 4 & 4 & 8 & 8 & 24 & 2,43 \\
\hline \multicolumn{2}{|c|}{ Podkarpackie } & 19 & 17 & 12 & 18 & 66 & 3,10 \\
\hline \multicolumn{2}{|c|}{ Podlaskie } & 5 & 6 & 6 & 13 & 30 & 2,54 \\
\hline \multicolumn{2}{|c|}{ Pomorskie } & 16 & 25 & 20 & 21 & 82 & 3,52 \\
\hline \multicolumn{2}{|c|}{ Śląskie } & 29 & 25 & 24 & 18 & 96 & 2,11 \\
\hline \multicolumn{2}{|c|}{ Świętokrzyskie } & 9 & 6 & 4 & 13 & 32 & 2,57 \\
\hline \multicolumn{2}{|c|}{ Warmińsko-Mazurskie } & 7 & 5 & 3 & 15 & 30 & 2,10 \\
\hline \multicolumn{2}{|c|}{ Wielkopolskie } & 25 & 16 & 22 & 20 & 83 & 2,38 \\
\hline \multicolumn{2}{|c|}{ Zachodniopomorskie } & 13 & 13 & 11 & 16 & 53 & 3,11 \\
\hline
\end{tabular}


voivodeships, the incidence of TBE did not exceed 0.9 per 100,000. (Table VII). The risk of tick-borne encephalitis is greater for people spending time near forests or in the woods, whether it is for recreation or work. That is why TBE most often concerns forest workers, farmers, students and pensiones (5).

In 2018, a total of 58,998 people received a last dose of the TBE primary vaccination course or a booster dose, i.e. 19,461 people $(49.2 \%)$ more compared to 2017. Most people were vaccinated in Mazowieckie voivodeship 16,259, least in Podkarpackie voivodeship - 1068 people. Such a large increase in vaccinations at TBE is amazing, despite the continuous increase in rejection of compulsory vaccinations (from less than 30,000 in 2017 to almost 40,000 in 2018), which indicates a lack of confidence in vaccines.

\section{SUMMARY AND CONCLUSION}

In 2018, was recorded an increase (by 14.7\%) incidence of meningitis and/or encephalitis compared to 2017 in Poland. This is mainly the result of an increase in the number of cases of meningitis other specified and unspecified. Thanks to vaccinations, no major increase was noted in $H$. influenzae, meningococcal and TBE infections. A large decrease in the number of cases of TBE may be due to a significant increase in vaccinations against tick-borne encephalitis. It can be assumed that the introduction of the mandatory vaccination against $N$. meningitidis may, in the long run, reduce the number of cases to the level of $H$. influenzae infections.

The number of infections with bacterial etiology in 2018 remains at a similar level as in the previous year, just like the incidence of bacterial infections, which remains at around 2.3 per 100,000. In contrast, viral infections have increased, which is mainly due to a greater number of viral meningitis of another specified and unspecified etiology.

In summary, we observe a general upward trend in the incidence, but mainly viral meningitis and/ or encephalitis of a different and undefined etiology. There was no noticeable increase in the incidence of bacterial infections with $H$. influenzae, $N$. meningitidis, or viral tick-borne encephalitis (TBE), which may indicate the effectiveness of vaccination. The only exception is $S$. pneumoniae infections, where an increase in the incidence has been noted. The presentation of the incidence by age group shows very well that the introduction of mandatory vaccination against $S$. pneumoniae brings very good results (most cases were related to adults). A significant increase in viral meningitis indicates basic diagnosis of meningitis and/or encephalitis, but insufficient detailed diagnosis of the etiology of these infections. padalność 4 na 100 tys.), co stanowi wzrost o $26,5 \%$ w stosunku do 2017 roku. W tej grupie najczęściej $(72,3 \%)$ diagnozowano zapalenia opon i/lub mózgu jako inne określone i nieokreślone wirusowe zapalenie opon mózgowo-rdzeniowych (1108 przypadków; zapadalność 2,88 na 100 tys.) (Tab. I).

Kleszczowe zapalenie mózgu (KZM). W 2018 r. zgłoszono ogółem 197 zachorowań na kleszczowe zapalenie mózgu (A84) w 13 z 16 województw (Tab. VII); zapadalność wyniosła 0,51 na 100 tys. W porównaniu do 2017 r. zachorowania oraz zapadalność spadły odpowiednio: o $43,6 \%$ i o $68,9 \%$. Najwięcej przypadków, podobnie jak w poprzednich latach, zarejestrowano na obszarach północno-wschodniej Polski, w województwie podlaskim (37\% ogółu zachorowań), warmińsko-mazurskim oraz mazowieckim (po 12,7\% wszystkich zachorowań). Największą zapadalność na KZM zanotowano w województwie podlaskim i warmińsko-mazurskim; wyniosła ona odpowiednio: 6,17 oraz 1,75 na 100 tys. co w porównaniu do poprzedniego roku jest znaczącym spadkiem (o ponad połowę). W pozostałych województwach zapadalność na KZM nie przekraczała 0,9 na 100 tys. (Tab. VII). Ryzyko zachorowania na kleszczowe zapalenie mózgu jest większe dla osób spędzających czas w okolicach zalesionych lub w lesie, niezależnie czy dotyczy to rekreacji czy pracy zawodowej. Dlatego KZM najczęściej dotyczy pracowników leśnych, rolników, osób uczących się oraz emerytów (5).

W 2018 r. dawkę szczepionki przeciw KZM kończącą cykl szczepienia podstawowego lub dawkę przypominającą otrzymało łącznie 58998 osób, tj. o 19461 osób (49,2\%) więcej w porównaniu do 2017 r. Najwięcej osób zaszczepiono w województwie mazowieckim 16 259, natomiast najmniej w województwie podkarpackim - 1068 osób. Wzrost osób zaszczepionych przeciw KZM wskazuje wzrost świadomości naszego społeczeństwa dotyczący etiologii choroby oraz możliwości zapobiegania poprzez szczepienia.

\section{PODSUMOWANIE I WNIOSKI}

W roku 2018 zarejestrowano w Polsce wzrost (o 14,7\%) zachorowań na zapalenie opon mózgowo-rdzeniowych i/lub zapalenie mózgu w porównaniu do 2017 roku., głownie przypadków zakwalifikowanych przez lekarzy jako zapalenia opon mózgowo-rdzeniowych innych określonych i nieokreślonych. Dzięki obowiązkowym szczepieniom, nie zanotowano wzrostu inwazyjnych zakażeń $H$. influenzae, meningokokowych oraz KZM. Znaczący spadek liczby przypadków KZM może wynikać ze znacznego wzrostu osób zaszczepionych przeciw kleszczowemu zapalenia mózgu. Pomimo braku obowiązkowych szczepień przeciw N. meningitidis sytuacja epidemiologiczna jest 
Obviously, this is a major challenge for the diagnostic and therapeutic process, but the improvement of this process may contribute to wider knowledge and its use for the treatment of patients and improvement of epidemiological surveillance in this area. Attention should be paid to the success of introducing vaccination against $H$. influenzae type B and $S$. pneumoniae into the vaccination schedule. Taking into account the reduction of diseases among children, it is possible to discuss extending the vaccination schedule with vaccination against $N$. meningitidis.

\section{REFERENCES}

1. Król ME., Borawski B, Nowicka-Ciełuszecka A et al. Outbreak of alimentary tick-borne encephalitis in Podlaskie voivodeship, Poland / Ognisko zachorowań na kleszczowe zapalenie mózgu nabyte drogą pokarmową na terenie województwa podlaskiego. Przegl Epidemiol 2019;73(2):239248. doi: 10.32394/pe.73.01.

2. Zbrzeźniak J, Paradowska-Stankiewicz I. Meningitis and encephalitis in Poland in 2017 / Zapalenia opon mózgowo-rdzeniowych i zapalenia mózgu w Polsce w 2017 roku. Przegl Epidemiol 2019; 73(4):417-427

3. Czarkowski MP. et al. Vaccinations in Poland in 2018, Warsaw 2019, NIZP-PZH, GIS.

4. Czarkowski MP. et al. Infectious diseases and poisoning in Poland in 2018, Warsaw 2019, NIZPPZH, GIS

5. Stefanoff $P$, Rosinska $M$, Samuels $S$ et al. A national case-control study identifies human socio-economic status and activities as risk factors for tick-borne encephalitis in Poland. PLoS One. 2012;7(9):e45511. doi: 10.1371/journal. pone. 0045511

Received: 09.06.2021

Accepted for publication: 21.06.2021

Otrzymano: 09.06.2021r.

Zaakceptowano do publikacji: 21.06.2021r.

\section{Address for correspondence:}

Adres do korespondencji:

Iwona Paradowska-Stankiewicz, MD, PhD

Narodowy Instytut Zdrowia Publicznego -

Państwowy Zakład Higieny

Zakład Epidemiologii Chorób Zakaźnych i Nadzoru

ul. Chocimska 24, 00-791 Warszawa

e-mail: istankiewicz@pzh.gov.pl porównywalna do 2017r. Można przypuszczać, że proponowane przez ekspertów wprowadzenie obowiązku szczepień przeciw $N$. meningitidis, mogłoby w dłuższej perspektywie czasu zredukować liczbę przypadków do poziomu zakażeń $H$. influenzae.

Liczba infekcji o etiologii bakteryjnej w 2018 roku utrzymuje się na porównywalnym poziomie co rok wcześniej, podobnie jak zapadalność na zakażenia bakteryjne, które utrzymują się na poziomie około 2,3 na 100 tys. Natomiast nastąpił wzrost zakażeń wirusowych, który jest spowodowany głównie przez większą liczbę wirusowych zapaleń opon mózgowo-rdzeniowych o innej określonej oraz niekreślonej etiologii.

Podsumowując, obserwujemy ogólną tendencję wzrostową zachorowań, ale głównie na wirusowe zapalenia opon i/lub mózgu o innej określonej i nieokreślonej etiologii. Nie zanotowano zauważalnego wzrostu zachorowań wśród bakteryjnych zakażeń $H$. influenzae, $N$. meningitidis, czy wirusowego zapalenia mózgu wywołanego przez kleszcze (KZM), co może świadczyć o skuteczności szczepień. Jedynym wyjątkiem są zakażenia $S$. pneumoniae, gdzie zanotowano wzrost zachorowań. Przedstawienie zachorowań w podziale na grupy wieku, bardzo dobrze obrazuje, że wprowadzenie obowiązku szczepienia przeciw $S$. pneumoniae przynosi bardzo dobre rezultaty (większość zachorowań dotyczyła osób dorosłych). Znaczący wzrost wirusowych zapaleń opon mózgowo-rdzeniowych wskazuje na prowadzenie podstawowej diagnostyki zapaleń opon mózgowo-rdzeniowych i/lub mózgu, natomiast niedostatecznego szczegółowego diagnozowania etiologii tych zakażeń. Jest to oczywiście duże wyzwanie dla procesu diagnostyczno-terapeutycznego, jednak usprawnienie tego procesu może przyczynić się do szerszej wiedzy i wykorzystania jej do leczenia chorych oraz poprawy nadzoru epidemiologicznego w tym zakresie. Należy zwrócić uwagę na sukces wynikający z wprowadzania szczepień przeciw H. influenzae typu B oraz S. pneumoniae do kalendarza szczepień. Mając na uwadze ograniczenie zachorowań wśród dzieci, można podjąć dyskusję o poszerzeniu kalendarza szczepień o szczepienie przeciw N. meningitidis. 